\title{
RECENT REFORMS IN FRENCH AND GERMAN FAMILY POLICIES \\ Similar challenges, different responses
}

Jeanne Fagnani, and Antoine Math

\section{Introduction}

Making a comparison between France and Germany in regard of their respective family policies is relevant. Indeed both countries belong to a cluster of countries whose welfare regimes are qualified as "conservative-corporative", sometimes also termed "Christian democratic", "continental", "corporatist-etatist", or "Bismarckian" (Arts and Gelissen, 2002; Martin and Palier, 2007; Van Kersbergen and Kremer, 2008). Notable features are high levels of spending and payroll tax financing with most benefits dependent on previous contributions and socio-professional status. As far as the main social insurance programmes are concerned, e. g. pension, health care and disability benefits, the French and German welfare states are consistent with this description. Their respective family policies also have much in common. Both are linked in several ways to employment policy and both are explicit, clearly defined, and generous in terms of cash benefits (Fagnani and Math, 2008).

The similarities end when we look at the provision of state supported child care facilities in both countries. Indeed, as late as the 1990s Germany still adhered to the "male-bread winner/female-caregiver" model (Lewis et al., 2008b; Ostner, 1993) while France had long since outgrown this model and already led the European Union in its efforts to provide childcare and benefits aimed at reducing costs for families (Gornick and Meyers, 2006; Morgan, 2006; Morel, 2007). Since this time however, dramatic changes in German family policies have occurred and legislators have increasingly placed more distance between themselves and the traditional model through the introduction of new laws in the domain of parental leave and child care provision. France, for its part has continued to progressively consolidate and enhance its promotion of policies to support the work/family life balance. Why did the German and the French governments introduce reforms in family policy? Are we currently witnessing a trend towards some measure of convergence?

By casting our eye through a comparative lens the aim of this paper is to focus attention on the family policies of both countries since the 1990s. Through careful analysis we will highlight a number of recurrent issues that help to illuminate and explain the differences that persist between France and Germany in spite of recent reform efforts. We need first therefore to examine the differing paths down which family policy has evolved over the years in the two countries. Next, we will give a comprehensive description of the work/family reconciliation policies already in place as well as the forces that have driven their creation. 
Finally, we will evaluate the success of these policies and whether they have achieved their desired effects on mothers' employment patterns, especially those of qualified female workers.

\section{Theoretical background and framework}

There exists a large body of literature examining the whole set of changes introduced individually in both France and Germany in family policies (Gornick and Meyers, 2006; Ostner, 2006; Henninger et al., 2008; Morel, 2007). More recent comparisons have tended to include a broader range of European countries producing results that provide a general picture as opposed to a more detailed analysis (Lewis et al., 2008b; Morgan, 2006). Other studies have concentrated on patterns of paid and unpaid work in Western Europe and their implications on public policy (Lewis et al., 2008a; Morel et al., 2009) and reforms in the care of children and the elderly have also received attention (Morel, 2007; Morgan, 2002). Another avenue of investigation was pursued by Klammer and Letablier (2007) by placing emphasis on the ways in which the contributions of enterprises and social partners have contributed to the development of work/life balance policies in both countries. Abrahamson (2007), in his case-study of four European cities located in Denmark, France, Germany and the United Kingdom, argued that past differences in welfare and family policy models are deeply entrenched and still influence attitudes and behaviour in everyday life.

What all of these studies have in common is that at the time of writing they were unable to evaluate the effects of more recent developments in childcare policies, not least the radical shift that occurred in Germany with the introduction of the new parental leave allowance (Elterngeld) in 2007. It is now possible to update and consider with the benefit of some hindsight the consequences of these changes while demonstrating their relationship to the contemporary dynamics of the workplace and how these are reflected in the attitudes of parents toward current reconciliation policies. Along this line, Himmelweit (2007: 594) convincingly argued that "policy both reflects and constructs the social norms and practices of a society". In accordance with this perspective, it is relevant to underline the values and norms governing childcare and mothers' employment patterns and investigate whether they fit in with the objectives of the recent measures or whether there is presently a mismatch between the two. This was the approach taken by Evers, Lewis and Riedel (2005), in a comparison made between 2002-2004 of England and Germany, which pointed out that "in Germany, the ambivalence inherent in policy making at all levels to do with the care of young children resonates with the views and behaviour of parents themselves". Thus, in order to fully capture the meaning, scope and impact of reforms we must place them within their wider institutional, economic and cultural context.

In analysing changes in reconciliation and childcare policies since the 1990s, borrowing from Hall (1993), we will distinguish at each stage:

- a process of first order change: the process whereby instrument settings are changed (i.e., the level at which child care benefits and related tax 
deductions are set), while the overall goals and instruments of policy remain the same;

- a process of second order change: when the instruments of policy as well as their settings, are altered even though the overall goals of policy remain the same;

- a process of third order change or paradigm shift: when a radical shift entails simultaneous changes in all three components of policy, the instruments settings, the instruments themselves, and the hierarchy of goals behind policy.

These three types of policy change are the variables used by Hall to breakdown and disaggregate the concept of "social learning" which is defined as a deliberate attempt to adjust goals or techniques in response to past experience and new information. Learning is indicated when policy changes are the result of such a process. This theoretical approach provides a useful framework with which to analyze the different approaches taken by France and Germany in the creation of a coherent and more comprehensive family policy.

\section{Methodology and data}

Our investigation was undertaken between 2007 and 2009 under the auspices of the National Family Allowance Fund (Caisse Nationale des Allocations Familiales, CNAF), the family branch of social security. To facilitate a deeper understanding of the way family policies have evolved in France and Germany since the 1990s we drew upon a diverse range of both qualitative and quantitative data:

- first, using the model family method, we compared the social and fiscal systems in $11 \mathrm{EU}$ member states (including France and Germany) and the ways in which they provide financial resources to households with children. Further analysis of these systems was conducted by making use of databases provided by Eurostat and the OECD;

- an evaluation of the "state of the art" for the current body of literature was carried out. Official documents and reports concerning the progress of reforms, and the laws and regulations associated with these, were the object of our investigations;

- data was collected from various national administrative and statistical bodies: Destastis, Germany's official statistics bureau; the French CNAF; and the Ministry of Work, Solidarity and Social affairs served as the primary sources of our information;

- policymakers; decision makers in the Federal Ministry of Family Affairs (BmFSJ); academic researchers; and the leaders of FamilienService, a large organisation which offers services to enterprises in the work/life balance policy domain, were invited to respond through a series of 18 interviews which took place in Germany. In France this was unnecessary as the attitudes 
of political, social and economic actors have been followed and analysed for a considerable period. ${ }^{1}$

\section{Family targeted social protection spending since the mid 1990s in France and Germany}

In both countries family policy still bears the traces of earlier history. For France this translates into a system of generous cash transfers (tax breaks and family allowances) with their roots in a long established natalist tradition which continues to favour large families (Baclet et al., 2007). Both countries make use of a non-taxable universal child benefit respectively named Kindergeld and allocations familiales. The financial resources allocated by Germany to direct cash transfers have in recent years surpassed those of France (table 1) as a direct result of significant increases in the amount of the Kindergeld over the course of the 1990s. These increases were made following decisions at the Constitutional Court in Karlsruhe (Bundesverfassungsgericht) in 1990 and 1992 (chart 1). Moreover, family benefits and tax breaks (Kinder-Freibeträge) underwent further increases between 1999 and 2002. ${ }^{2}$ The total "family/children" cash benefit expenditure as measured by Eurostat increased from $1.5 \%$ to $2.5 \%$ of GDP in Germany between 1995 and 2005 whereas it decreased from $2.3 \%$ to $2 \%$ of GDP in France (chart 1). Furthermore, when one takes into account the demographic makeup of both countries - the share of children in the total population is much lower in Germany than in France - the scale is tipped yet further in Germany's favour.

By making use of the model family method, ${ }^{3}$ it is clear to see that levels of financial support to parents of one or two children - taking into account the full range of tax incentives, family, and housing benefits - are higher in Germany than France, regardless of income levels. For parents of three or more children however France provides a more generous package. Additionally, in Germany as in France, the taxation system still favours married couples where only one of the spouses is in paid work though in Germany parents can choose between joint and individual taxation.

A rapid rise in the levels of family targeted social spending in Germany during the 1990s saw the country overtake France in this area and we could reasonably expect a corresponding increase in fertility levels. That this has patently failed to

1 Jeanne Fagnani is also a member of the board of directors of a Family Allowance Fund (Val-de-Marne department).

2 The amount of Kindergeld granted for one child rose from DM 50 in 1990, to DM 220 in 1997 and DM 301 in 2002. For the second child, it was respectively DM 130, DM 220 and DM 301 (Dingeldey, 2006).

3 The method consists of calculating and examining the structure and level of the family benefit package for a range of families by taking into account both the number of children and levels of earnings. The family benefit package is therefore the supplement made to a household's net disposable income and how it compares to a childless couple on the same earnings after the main transfers and taxes for the family with children have been taken into account. This difference represents the contribution of public policies in respect to children (and being a lone parent). 
Table 1 "Family-children" related expenditures as a percentage of GDP and as a percentage of total social benefits (2006)

\begin{tabular}{lcc}
\hline & \% of GDP & \% of total social benefits \\
\hline France & 2.5 & 8.6 \\
Germany & 3.2 & 11.1 \\
\hline
\end{tabular}

Source: Eurostat, Statistics Database, 2010

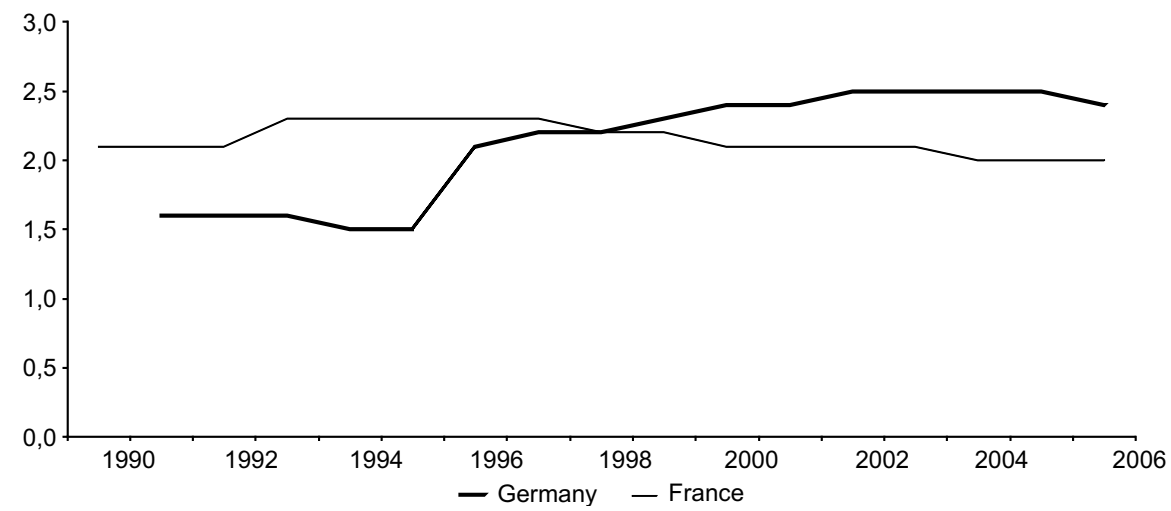

Figure 1 Public family spending in cash as a percentage of GDP: evolution 1990-2006

Source: Eurostat, Statistics Database, 2010.

occur should come as less of a surprise if we take a broader perspective and move beyond the system of cash transfers to consider the overall childcare package, including benefits in-kind, where France remains far more generous.

More resources committed to childcare policies in France than in Germany

As a result of longstanding traditions that stretch back to the late nineteenth century (Morgan, 2002), France spends much more overall than Germany on childcare services (table 2). The former West Germany (Old Länder) was a long time a laggard country in childcare provisions but can no longer be viewed as a low spender when compared to other European countries (OECD, 2009). However, despite significant German improvements in this area since the turn of the millennium and a law passed in 2005 (see pp. 16 ff.), France still devotes a larger share of GDP to childcare services such as écoles maternelles (nursery schools) and spending per child as estimated by the OECD is measurably higher in France than in Germany (table 2). The differences become even more pronounced if we look at facilities provided for children under 3 years of age. 
Table 2 Public expenditure on childcare and early education services in France and Germany as a percentage of GDP (2005)

\begin{tabular}{lccccc}
\hline $\begin{array}{c}\text { Public } \\
\text { expenditure on } \\
\text { childcare services } \\
\% \text { of GDP }\end{array}$ & $\begin{array}{c}\text { Public } \\
\text { expenditure on } \\
\text { early education } \\
\text { services } \% \text { of } \\
\text { GDP }\end{array}$ & $\begin{array}{c}\text { Public } \\
\text { expenditure on } \\
\text { childcare and } \\
\text { early education } \\
\text { services } \% \text { of } \\
\text { GDP }\end{array}$ & $\begin{array}{c}\text { Public } \\
\text { expenditure per } \\
\text { child on } \\
\text { pre-primary } \\
\text { education in US\$ } \$ \\
\text { (PPP converted) }\end{array}$ & $\begin{array}{c}\text { Public } \\
\text { expenditure on childcare } \\
\text { (PPP cort in US } \$\end{array}$ \\
\hline France & 0.36 & 0.64 & 1.00 & 4679 & 2858 \\
Germany & 0.07 & 0.31 & 0.38 & 3538 & 860 \\
\hline
\end{tabular}

Source: OECD (2009), Family Database. Public expenditure on childcare and early education services, per cent of GDP (chart PF 10), http://www.oecd.org/dataoecd/44/20/38954032.xls

For French families the fortunate reality is that the range of measures to help working parents have been expanded yet again (Fagnani, 2009). Public expenditures paid by the CNAF and directed toward collective childcare facilities have risen steadily over the last decade and despite an overall background of cost containment in other public services, the system of public crèches has suffered no cutbacks in funding. These and other measures go some way toward offering an explanation for the persistent gap that exists between the two countries when measuring the overall provision of childcare and services for working parents.

\section{Reforms in childcare and parental leave policies in France and Germany: first order change versus third order change?}

Since the 1990s, against the background of an increase in female employment rates and alongside societal processes working hand in hand to shape provision and demand, both the French and German governments have sought to expand childcare facilities but from decidedly different starting points that explain differences in reaction to similar challenges. Despite some evidence of convergence between the two countries differences remain striking in respect to level of supply; modes of governance; opening hours; patterns of provision; funding; and the division of responsibility for care between the state, the market and the family.

\section{A brief account of changes in reconciliation policies since the 1990s:}

dramatic shifts in Germany, piecemeal measures in France

Unification has played a major role in the subsequent evolution of reconciliation policies in Germany. The bilateral unification contract (Einigungsvertrag) explicitly states that a unified Germany must "strengthen the legal position of working mothers and fathers in regards to work/family reconciliation" and preserve the East's extensive childcare infrastructure (Ostner, 2006; Dingeldey, 2006). Negotiations to harmonise abortion legislation (more flexible in the former German Democratic Republic) gave rise to a decision by the country's Constitutional Court which 
compelled the government led by Chancellor Helmut Kohl to introduce reforms in state provision of childcare despite opposition from his own party. In 1996 a law was passed making it mandatory for local authorities to offer all children between the ages of 3 and 6 the opportunity to attend a Kindergarten. To compensate for years of neglect the state agreed to subsidise local authorities in order to ensure that the provisions of the new law were carried out. As outlined by Meyer (2005: 288) "without unification and the ruling of the Constitutional Court, it is doubtful that such a decision would have been made at the time".

While the road ahead would remain long and winding the foundations for the future were firmly laid between 1992 and 1999. During this period 600,000 Kindergarten places were created in the Old Länder and annual expenditures for these structures rose from EUR 8.5m to EUR 10m. Enactment of a 1996 Law has ensured that since 1999 virtually all children between the ages of 3 and 6 attend Kindergarten, usually on a part-time basis. The question of care for infants aged less than 3 years was conveniently pushed to one side and forgotten until recent years. Meanwhile, with the arrival of the first "red-green" (SPD-Die Grünen) coalition government under Chancellor Gerhard Schröder, family policy was the object of further realignments from 1998 to 2002. In order to challenge previously held assumptions on parental responsibilities the instrument settings of family leave policies were softened and made more flexible in 2001. Parents were in most cases given permission to work part-time up to 30 hours per week during parental leave whereas previously it had been limited to 19 . The system for calculating the levels of the childrearing benefit remained unchanged however and continued to be income related and rather modest.

Along with the second mandate of the red-green coalition came the introduction of more radical reforms to family policy that we can qualify as of a "second order change". Passage of these measures was greatly eased by the support of leaders in the private sector who were struggling to find qualified personnel and needed new incentives to recruit and retain qualified staff. In 2002 the coalition government declared its objective to create 30,000 new places for children aged under 3 years by the year 2012 in the Old Länder (Bode, 2003). This proposal met with opposition from the conservative dominated Federal Council, Bundesrat, ${ }^{4}$ which used its power of veto to quash the measure citing financial concerns. The Federal Parliament overrode its decision with an act that provided the legal groundwork for future legislation to expand childcare facilities (Tagesbetreuungsausbaugesetz - TAG) using as a precedent the $2002 \mathrm{EU}$ Summit in Barcelona where a resolution was passed to eliminate disincentives to female participation in the labour force by recommending that at least $33 \%$ of children under the age of 3 have access to some form of early childhood care. Drafted into law and effective from January 2005 local authorities are now responsible for providing childcare facilities to all children under 3 whose parents are working, undergoing professional training, or as the need arose by the year 2013. Roughly a third of this care will be provided by registered child 
minders as they represent a less expensive option than the construction of more childcare facilities.

Reforms reached a further crescendo in 2006 following legislation on the introduction of a new parental leave allowance (Elterngeld) which represented a radical departure from previous tradition. Using the Swedish model for inspiration and effective from January 2007 the new gender neutral scheme allows parents to claim $67 \%$ of their previous average net income in the 12 months preceding the birth of the child. ${ }^{5}$ The Elterngeld is granted for a minimum of 1 year and is non-taxable. In order to avoid what political representatives from the SPD and the Green party described as "a redistribution from the poor to the rich" (Erler, 2009), the government introduced a minimum benefit level of EUR 300, regardless of prior employment status, and a maximum benefit ceiling of euros 1800 per month.

As a corollary to this new policy, fathers are being encouraged to play a greater role in family life than has traditionally been the case in Germany. When the Elterngeld is shared between partners they can extend the period for which it is received from 12 to 14 months. To avoid penalising low paid parents whose relevant income is less than EUR 1000 a month the allowance can be adjusted upwards from $67 \%$ in the form of a low income supplement.

To overcome the challenge of re-entering the workforce after extended periods of absence recipients of the allowance are encouraged to maintain their links to the labour market and in most cases - employees of small to medium sized enterprises must first be granted permission from their employer - are allowed to work part-time up to 30 hours per week. The income earned from this work is taken into account when calculating the amount of the parental allowance. Flexibility is the key here and in this respect the Elterngeld can facilitate a wide range of arrangements between parents. They could for example share the time during which they receive the benefit either simultaneously (in which case each would receive seven months parental leave) or successively with one parent following the other. Instead of 12 months, the period of payment may be spread over 24 months (plus 4 months if the other parent takes it up) but the monthly benefit level is reduced so that the overall payment remains the same.

The German law that allows parent to take up to 3 years of parental leave (Elternzeit) remains unaffected by the new legislation and employers are legally obliged to keep the parent's job open for the duration of this period. With permission from the employer one year of the leave can be deferred to be used when the child is between the ages of 3 and 8 . For parents in the public sector deferral can be extended until the child's 18 th birthday if they have more than one child and often up until the age of 12 in the private sector. One of the primary goals of these measures is to eliminate the financial challenges many women must face when choosing between their career and motherhood. Indeed, the assumption is that

5 Within the austerity package announced in June 2010 by the government headed by Chancellor Angela Merkel, recipients of the Elterngeld with a net monthly income of over 1,240 euros will be provided with 65 percent of their income prior to the birth, rather than the current rate of 67 percent. 
many career-oriented women avoid motherhood altogether as it would involve such a large loss of income (Spiess and Wrohlich, 2008) thus every effort is made to make the transition back to professional life as smooth as possible.

In France, unlike Germany, the "male-breadwinner" model began its steady decline in the 1970s following a dramatic increase in the levels of women entering the workforce in the 1960s. Over time, and especially since the 1980s, this trend has only accelerated (Fagnani, 2006). From the 1990s onwards, and against the background of a dramatic rise in unemployment rates, the right-wing government decided, in 1994, to exploit the job creating potential of the childcare sector by dramatically increasing child care allowances provided to working parents who relied on registered child minders, or home helps such as nannies, and at the same time introduced special tax breaks in order to help families better meet the costs of these "individualized" child care arrangements. The government hoped to encourage families with children to create employment and at the same time bring more domestic workers into the formal economy. Government officials adopted such language as "freedom of choice for parents", and "diversification of childcare arrangements" to draw popular support. Family policy was transformed by successive governments who began to use it as a tool to fight unemployment while neglecting to address the fundamental nature of "the working mother" model.

In 2004 the government wanted to reaffirm its traditional benevolence toward family related issues and introduced incremental reforms against a more general background of cost containment in Social Security. Using the rhetoric of "simplification" of the childcare allowances system and the promotion of "freedom of choice for parents" these first order changes were a reflection of the ambiguities and hybrid nature inherent in French family policy and included two primary adjustments:

First, policymakers implicitly acknowledged the social inequalities faced by parents - especially in terms of access to quality childcare services - by significantly increasing the amount of the income related childcare allowance in cases where low income dual earner families were seeking to employ the services of a registered child minder. Secondly, previous to 2004, the childrearing benefit (CRB) was only available to the parents of at least two children but in 2004 was extended to parents of a single child and renamed the "Supplement for the freedom of choice to work or not". This allowance, rather modest and paid at a flat rate is received for up to six months after maternity or paternity leave but can be extended to 3 years when there are two or more children present. The aim of this adjustment was both to limit expenditures and to reduce the time spent by mothers outside the labour market. Additionally, the proportion of the CRB paid to parents who choose to work part-time has gone up (but this amount remains lower than the amount paid to those who stop working completely). This financial incentive has proven its efficiency and has sharply increased the number of recipients working part-time while receiving the benefit.

To fully comprehend why French reforms were somewhat limited in scope we need to understand that reigning in spending has become of primary concern to the governments of recent years. While family policy has remained largely untouched 
by the overall culture of belt tightening that has invaded other areas of the social protection agenda - such as the pension and healthcare regimes - it is highly unlikely that the adoption of a German style Elterngeld will receive any consideration in the current climate as the shift from a low flat rate benefit to a wage-related benefit would be far too costly. Instead the focus has continued to remain on boosting employment figures and the approach taken by the government since the year 2000 has been to continue supporting mothers' employment by subsidising both formal individual childcare arrangements as well as collective ones. In addition, and in contrast to Germany, the issue of gender equality remains low on the family policy agenda despite modest moves towards a more egalitarian gender model. In 2002 the socialist government established a "paternity leave" that was extended from three to eleven days and paid at full rate under a certain ceiling by social insurance funds. This new measure was a runaway success and more than three-quarters of fathers took advantage of the new benefit.

\section{Drivers for third order change in Germany}

The numerous and intertwined factors that have led to a process of "third order change" in Germany have occurred in a political and economic climate favourable to reform. Despite steadily rising levels of state support for families during the 1990s fertility levels have remained stubbornly low (see pp. 14-16) and an example of 'evidence-based learning' took place (Dolowitz and Marsch, 2000) as the country struggled to find solutions to this problem. Drawing from the experiences of Sweden and France (Bothfeld, 2005; Erler, 2009; Fagnani and Math, 2007) - two countries that have successfully combined high fertility with high rates of employment for mothers (Morgan, 2006) - policymakers were able to reach political consensus over the necessity for comprehensive changes in German reconciliation policies.

\section{A shortfall of qualified workers}

An increasingly competitive economic environment served to highlight a chronic shortfall of qualified staff in German enterprises and the potential for filling this gap by increasing female participation in the labour market was not lost on employers (Holst, 2005). Additionally, a burgeoning low wage service sector was also in desperate need of staff and again it was hoped that women could help make up the shortfall. In acknowledgement of this untapped potential, employer organisations gave their full backing to the Family Ministry, which was led by Renate Schmidt (SPD) from 2002 to 2006. Her successor Ursula von der Leyen (CDU) has continued the policies initiated by her predecessor despite her conservative party affiliation and has benefited from the unconditional backing of Chancellor Angela Merkel. While decisions taken by the Ministry were often the targets of virulent criticism employers continued to give their unwavering support. When a proposal was made to triple the number of places available in crèches by the year 2013 it received the full backing of the President of the BASF group as well as industry leaders from Bosch and Thyssen-Krupp. In France such measures have been largely unnecessary due in no small part to the fact 
that, despite some progress being made during the 1980s in the Old Länder, the percentage of women participating in the labour market in Germany has never been able to catch up with France.

Pension reform and low fertility: what is at stake?

Controversy surrounding pension reform, along with fading memories of the demographic policies under the National-Socialist party, created an atmosphere in which it became possible and desirable to confront the long standing challenge of declining fertility in Germany (Ostner, 2006; Bertram et al., 2005). Although reluctant to enter a quagmire which dates from the late-1960s onwards ${ }^{6}$ the political authorities used this opportunity to increase public awareness of the "graying" of the population in the hope that this might have a positive effect on reproductive behaviour. Further impetus for change came in 2001 in the form of the results of an OECD investigation into the educational performance of its member countries.

Publication of the PISA study: shattering of certitudes

Previously held assumptions on family policy were shaken to their core by the publication in 2001 of data collected during 2000 PISA assessment of the educational infrastructure across member countries (OECD, 2001). Germany was effectively placed 21st out of 32 countries and in the ensuing media firestorm the system of early childhood education was being held to account for these unsettling results. Contained within the report were recommendations on the importance of a public system of early childhood care for the socialization and development of children which called into question the very foundations of German family policy. According to the social norms in place at that time it was taken for granted that the most positive environment for children was at home with their mother. To remedy the situation the federal government took steps which led initially to a decision taken in 2003 to allocate subventions totaling EUR 4 billion to the Länder in order to allow them to expand and develop early childhood facilities capable of operating throughout the day. Whether the steps taken have been successful will be examined in the next section and we must further take into account the fact that German salaries declined between 2001 and 2007 by $-0.8 \%$ whereas in France they actually rose by $1.5 \%$ (IMK, 2008). Within the context of deflationary pressure and negative salary growth authorities are being forced to respond to the increasing demand for childcare (Wrohlich, 2008) as more and more mothers enter the workforce in order to maintain their family's previous held standard of living.

6 In 1970, total fertility rate (TFR) in the FRG was already much lower than in France: respectively 1.99 and 2.47; ten years later, 1.45 and 1.95 (Eurostat, 2009).

SOCIOLOGIA, PROBLEMAS E PRÁTICAS, n. ${ }^{\circ}$ 64, 2010, pp.11-35 
Investing in the future: important developments in childcare provisions for both countries since the 1990s

Longstanding cultural and institutional obstacles have dampened the pace of childcare reforms in Germany and have led to a patchwork policy in which all childcare is provided at the municipal level, by local non-profit providers or NGOs (often members of large non-profit welfare associations, Wohlfahrtsverbände) and churches. A mere $1 \%$ of the market is covered by for-profit providers (Muehler, 2008). The highly decentralized federal structure and its multiplicity of stakeholders (Evers et al., 2005) have resulted in a tangled web that has increased the complexity of the system in terms of finances and organisation. ${ }^{7}$ This offers a partial explanation for the sluggish development of explicit childcare policies in Germany.

In France on the contrary, child-care policy is highly centralized. As far as individualized childcare arrangements are concerned, i.e. registered childminders, benefits and tax breaks are entirely defined at the national level. In regard to collective childcare facilities the rules that govern their organisation, levels of public funding, and the setting of fees (income-related) to be born by the parents, are set up nationally following guidelines fixed through accords signed every four years between the government and the CNAF (Convention d'Objectifs et de Gestion). The latter coordinates the large network of 123 Family Allowance Funds (CAF) that implement the childcare policies. However, local authorities, especially municipalities, are left with some margin for manoeuvre in the provision and development of childcare services.

Germany: steps in the right direction but the picture remains far from complete

In the Old Länder the supply of places in some kind of formal childcare arrangement (Tageseinrichtungen or Tagespflege) for children under the age of 3 has remained weak despite modest increases since 1994 (Wrohlich, 2008) (table 3). In the states of the former-GDR, where prior to unification the childcare infrastructure was extensive and widespread, the number of places on offer has in fact declined as a result of both increases in female unemployment and the closure of enterprises that had previously provided childcare facilities to employees. The previously mentioned parental leave scheme (Elternzeit) has also acted as a discouraging factor for mothers when calculating the benefits of returning to professional life before the child reaches 3 years of age (Grandke, 2001).

The gap that exists between supply and demand of formal childcare in Germany owes much to the considerable cultural and institutional obstacles which

7 In line with the principle of subsidiarity policy-making is defined at the municipal and district level with voluntary-sector providers (mainly churches) usually taking part in planning and decision making. Management of Kindergarten is the responsibility of the municipalities while in France nursery schools are part of the school system and under the supervision of the Ministry of Education. 
Table 3 Percentage of children aged under 3 attending childcare facilities or being cared for by child minders* in Germany: evolution 1994-2009

\begin{tabular}{lccc}
\hline & December 1994 & March 2007 & March 2009 \\
\hline Germany & 6.3 & 15.5 & 20.4 \\
Old Länder & 2.2 & $8.1^{* *}$ & - \\
New Länder & 41.3 & $37.4^{* *}$ & - \\
\hline
\end{tabular}

Source: Destatis, 2008 and Statistisches Bundesamt: Statistisches Jahrbuch, 2007 and Statistisches Bundesamt, 2009, http: //www. bpb. de/wissen/32UOZK, 0, Familie_und_Kinder. html

Notes: * "öffentlich geförderter Kindertagespflege"; ** without Berlin

have stood in the way of reforms since the 1970s. Despite a decrease in the number of births per year - down from 767,000 in 2000 to 682,524 in 2008 - provision remains far from adequate. This penury has been exacerbated by the current economic crisis and its effect on the public finances of local authorities who are responsible for a third of all construction costs - the rest being provided by state and federal funds related to childcare facilities. Reforms in the pedagogical foundations of early childhood education along with recent negotiations over salary increases for childcare staff threaten to slow down even further the expansion of suitable early childcare provision (Muehler, 2008). Because of the head start provided by its long tradition of benevolence in childcare provision, France has continued to multiply the options available to parents of young children creating an ever widening distance between the two countries in the domain of family policy.

France and the growth of state supported childcare

From the mid-80s until the end of the 1990s publicly subsidized individual childcare arrangements began to be promoted over collective ones not least because of their lower cost but even more importantly because they would help boost employment figures by integrating childminders into the formal economy. Since the beginning of the 21st century however the government has had to respond to increasing pressure from parents and advocacy groups by revising this policy and injecting more cash into the development of collective arrangements such as primary schools and crèches. Between 2003 and 2007 the number of places made available to children in such arrangements rose $2.9 \%$ per year and by 2007 there were 14 places for every 100 children aged under 3 in these publicly subsidised childcare centres (Bailleau, 2009; CNAF, 2009). Although measures are being taken to compensate for a persistent shortfall in supply policymakers have yet to satisfy the ceaseless demand for these facilities, a problem aggravated by the fact that the number of children born in 2008 rose to 834,000 from 776,000 in 1999.

The primary method for bridging the gap between supply and demand for childcare has been to increase government support for registered child minders who currently satisfy the bulk of the demand for care, for children under 3 living with working parents (if families with one parent on parental leave are not taken into account): according to a 2007 survey on childcare arrangements (Ananian and 
Robert-Bobée, 2009), around a quarter of children below the age of 3 were being cared for by a registered child minder, $18 \%$ as their main childcare arrangement on weekdays (between $8 \mathrm{AM}$ and $7 \mathrm{PM}$ from Monday to Friday). ${ }^{8}$ Crèches provided care for a further $18 \%$ of children under 3 but only $10 \%$ made use of such facilities as their primary childcare arrangement. A further $7 \%$ were attending nursery schools (écoles maternelles), but a mere $2 \%$ as their main childcare arrangement. According to the 2006 EU-SILC Eurostat survey, $31 \%$ of children under the age of 2 receive care from sources outside the family compared to $19 \%$ in Germany. The actual difference is even greater as data for France does not record the numbers of children being cared for by registered child minders when payment is made directly by the parents.

Differences regarding collective childcare supply in Germany and in France

For further evidence of the gap between the two countries we can examine the modalities of care for children aged under 2 years of age according to the 2006 EU-SILC Eurostat survey: in France, 17\% are in formal childcare arrangements for 30 hours or more per week, compared to only $8 \%$ in Germany. As for children between 3 years and the statutory school-age, $42 \%$ spend 30 hours or more in a nursery school per week in France while this is the case for only 26\% in Germany. These variations feed off and follow a similar pattern to the differences found in the share of mothers working part-time in the two countries (see further).

\section{Child-raising norms: differences between France and Germany}

\section{Persistent features regarding child-raising norms in West Germany}

Public opinion has remained ambivalent on the question of the desirability of collective childcare facilities in the Old Länder. It is revealing that the design of the new Elterngeld was clearly inspired by the Swedish parental leave scheme: the underlying assumption was that the establishment of a one-year leave was in tune with the widespread belief that it was better for the child's well being to be cared for at home by the parents (in particular the mother) until the age of 1 . In France, the decision by many working mothers to place their children in the care of a crèche or registered child minder has become socially acceptable while in West Germany such a decision continues to raise eyebrows. The Old Länder still demonstrate a somewhat conservative attitude to the changes that are taking place and we can

8 Unlike their German counterparts, child minders in France are closely supervised by the "Protection Maternelle et Infantile" (PMI services). This statutory service is responsible for the health care of children under six years old and plays a supervisory role for all public and private child care provisions. Child minders are required to register with local authorities, a procedure that allows parents who rely on them to be eligible for the related childcare allowance. In Germany, child minders who are self-employed are unregulated and there are no reliable records as to their numbers (Evers et al., 2005; Muehler, 2008). 


\begin{tabular}{|c|c|c|c|}
\hline & $\begin{array}{c}\text { A pre-school is more likely } \\
\text { to suffer if his/her mother } \\
\text { works }\end{array}$ & $\begin{array}{l}\text { Ideally the woman should } \\
\text { stay at home to look after } \\
\text { the children }\end{array}$ & $\begin{array}{c}\text { All in all family life suffers } \\
\text { when the woman has a full } \\
\text { time job }\end{array}$ \\
\hline West Germany (Old Länder) & 21 & 17 & 27 \\
\hline $\begin{array}{l}\text { East Germany (New } \\
\text { Länder) }\end{array}$ & 6 & 7 & 9 \\
\hline France & 14 & 8 & 13 \\
\hline
\end{tabular}

Source: Eurobarometer, 2006.

observe that even among more recent generations of women - aged 15-39 - there is still a long way to go before there will be a degree of convergence with the prevailing norms found in France, or the New Länder (table 4).

Furthermore, in a survey of German parents of children aged under 6 the results indicated that only $15 \%$ supported the idea of full time employment for mothers while $66 \%$ felt that part-time work was the more suitable option and $10 \%$ felt that women should cease working altogether (Institut für Demoskopie Allensbach, 2007). These results illustrate once again that "Social norms and values influence the allocation of care and caring responsibilities" (Himmelweit, 2007: 581). As we will see in a moment the choices mothers continue to make in regards professional life are profoundly shaped by longstanding attitudes towards what constitutes "correct" behaviour for women.

\section{Outcomes of the reforms in terms of mothers' employment patterns}

Along with the development of childcare policies, female labour force participation has been increasing in both countries since the 1990s. In Germany, the employment rate for women (25-49 age cohorts) was $73.3 \%$ in 2007 , compared to $75.1 \%$ in France (OECD, 2009). As far as maternal employment rates are concerned however, differences between the two countries are more illuminating (table 5): irrespective of the number of young children in their family, mothers living in France are more often employed than their German counterparts. For parents who have at least one child aged less than 3 years, respectively $46.7 \%$ and $31.9 \%$ are in paid work. The reality is that much of the growth in employment rates for German mothers is attributable to the rise of part-time work (table 5).

For both countries we can observe that for couples with at least one child under the age of 6 the traditional model of the "stay at home mother" has been in steady decline since the mid-90s. The impact of this process and the subsequent reassessment of previously accepted norms began in Germany in the nineties when the then dominant "male breadwinner model" was gradually replaced by a modified version of its former self - a "modified male breadwinner model" (Pfau-Effinger, 2005) - in which fathers work full time while mothers opt for part time work. The dual earner model has been slow to develop and remains the least popular choice for parents (19.6\%) while in France it has become the most widespread 
Comparison of employment patterns of parents in Germany and France (2007)

\begin{tabular}{lcc}
\hline & Germany & France \\
\hline \multicolumn{3}{c}{ Maternal employment rates by number of children under 16 } \\
\hline 1 child & 74.2 & 78.9 \\
2 children & 67.7 & 75.4 \\
children & 51.2 & 56.9 \\
\hline
\end{tabular}

Employment patterns for couple parent families with a child under 6 in Germany and France: evolution 1994-2007

\begin{tabular}{llll}
\hline Both parents work full-time & 1994 & 20.6 & 37.1 \\
Man full-time, woman part-time & 2007 & 19.6 & 38.4 \\
& 1994 & 21.6 & 16.7 \\
Man full-time, woman not working & 2007 & 34.7 & 21.8 \\
& 1994 & 47.1 & 38.5 \\
\hline
\end{tabular}

Distribution of working hours among women in couple families by age of mother and number of children aged $0-14$ years in Germany and France

\begin{tabular}{|c|c|c|}
\hline \multicolumn{3}{|c|}{ Women with one child } \\
\hline$<29$ & 50.7 & 19.5 \\
\hline $30-39$ & 27.4 & 58.8 \\
\hline $40+$ & 22.0 & 21.8 \\
\hline \multicolumn{3}{|c|}{ Women with 2 or more children } \\
\hline$<29$ & 68.3 & 26.9 \\
\hline $30-39$ & 17.1 & 50.7 \\
\hline $40+$ & 14.6 & 22.4 \\
\hline
\end{tabular}

Source: OECD, Family Database, 2009-07-13, www.oecdorg/els/social/family/database

(38.4\%). Irrespective of family size the majority of German mothers who work do so on only a part-time basis while more than $73 \%$ of their counterparts in France are engaged in full-time employment of more than 30 hours per week (table 5).

When we take into account the shortcomings of policies directed at childcare facilities along with the weight of traditional norms on the modalities of care within the family it should come as no surprise that motherhood has a far more significant impact on employment in Germany than in France: the difference between the employment rate of women (aged between 20-49 years old) without children and the employment rate of women with a child aged less than 6 was - 26.5 points in Germany and - 9.7 points in France (Eurostat, 2008). The questions we must ask now are related to whether the introduction of the Elterngeld in 2007 has been effective in addressing this issue by allowing parents to suspend professional activity in the year following a child's birth: have the financial incentives to take up this leave been efficient? And, did a significant share of fathers take advantage of this scheme - to stop working or work part-time - in order to devote more time to family responsibilities?

Recipients of the Elterngeld scheme: reasons to be cheerful?

While at the time of writing it is still too early to assess any long term impact the new parental allowance scheme is having on the employment pattern of parents of 
Table 6 Recipients of the Elterngeld according to gender and length of take up (from 01/2007 to 06/2008) (children born in 2007)

\begin{tabular}{|c|c|c|c|c|}
\hline & $\begin{array}{l}\text { Share of men and } \\
\text { women in the total of } \\
\text { recipients } \\
(751,941)\end{array}$ & $\begin{array}{c}\% \text { of those who take } \\
\text { it up only } 2 \text { months } \\
\text { or less }\end{array}$ & $\begin{array}{l}\% \text { of those who take it } \\
\text { up between } 2 \text { months } \\
\text { and less than } \\
12 \text { months }\end{array}$ & $\begin{array}{l}\% \text { of those who take } \\
\text { it up } 12 \text { months }\end{array}$ \\
\hline Fathers & $13.7 \%$ & 67.2 & 19.2 & 12.9 \\
\hline Mothers & $86.3 \%$ & 1.2 & 10.2 & 88.6 \\
\hline
\end{tabular}

Source: Destatis (2009), Statistisches Bundesamt, https://www.ec.destatis.de/csp/shop/sfg/bpm.html

young children, the early indicators have been relatively encouraging when we consider the challenges the reforms intended to address. Less than a third of all mothers have returned to the workplace upon expiration of the allowance at the end of the first year (BmFSFJ, 2009). After two years the numbers are more encouraging: $42 \%$ (the parent can be provided with the Elterngeld for up to two years but the total amount is equal to that received if only one year is taken). However women who were already in full-time employment before the birth of a child are much more likely to return to work quickly: $50 \%$ have re-entered the workplace after the first year and indeed many after only a matter of months. Usually these mothers re-enter the workforce on reduced hours: prior to childbirth the average time spent working was 32 hours per week whereas at the end of the one year parental leave period the average had dropped to 25 hours. ${ }^{9}$ A shortage of adequate childcare offers a partial explanation for these figures and it goes without saying that the general trend towards shortening the duration of parental leave has led the local authorities to something of an impasse where demand far outreaches levels of supply: as recently as March 2009 the childcare infrastructure, whether collective or individual, was capable of providing for only $29.4 \%$ of children aged between 1 and 3 (Statistisches Bundesamt, 2009).

The goal of encouraging fathers to take a more active role in parental responsibilities has met with less success: they represent only $13.7 \%$ of the beneficiaries of the family allowance with a mere $3.3 \%$ of those eligible choosing to take advantage of the new measures (table 6). For the fathers who have chosen to claim the Elterngeld the majority $(67.2 \%)$ limit the period in which they receive it to the two supplementary months reserved for parents who choose to share the allowance. Moreover, among them, $29 \%$ continue to work on a part-time basis compared to only $13 \%$ of mothers. For many fathers the current measures fail to make up for the significant loss of income that would result from an extended parental leave.

9 Source: OECD (2009), Family Database, table LMF5. 1: Average annual earnings of females as a percentage of males, www.oecd.org/els/social/family/database 


\section{Conclusion and discussion}

Germany's and France's family policies are moving towards convergence. Still in the 1990s, the family policies of France and Germany demonstrated few common interests but in more recent years it is undeniable that they have begun to overlap with one another despite different starting points that explain differences in reaction to similar challenges. This is especially true when we consider their shared objective to promote and support the "dual-earner model".

The reforms adopted by Germany since the 1990s, and in particular after 2005 , represent a radical departure from traditional norms and have made this convergence possible. Indeed these reforms can clearly be classified as representative of a process of third order change (Hall, 1993). There have been simultaneous reorientations of all three policy components: the instrument settings (the shortage of qualified workers, the ageing of the society, the persisting fertility decline), the instruments themselves (development of childcare provision for under 3's, the new parental leave scheme), and the hierarchy of goals that support the policies (attracting qualified women on the labour market, promoting mothers' employment are now high on the policy agenda). Whether this process will be enough to make up for ground lost over the years previous to reform remains however an open question and Germany still lags behind France if we measure the two countries in terms of ability to successfully introduce more progressive child care policies.

In France changes have been incremental and represent a process of first order change. Issues related to the work/life balance have rarely strayed from their stable trajectory and have largely developed in accordance with the "path dependency" theory. Spending on policies related to childcare has been largely insulated from the general culture of cost cutting in other areas of the social protection agenda and has actually been rising rapidly. Meanwhile recipients of the parental leave allowance are being encouraged to retain their links to the workforce through the increase in the allowance for those who choose to work part time (while there was no increase whatsoever for those who stop completely to be in paid work).

There are still however significant differences between the two countries. In Germany the foundations of the new Elterngeld scheme are based on the belief, still widespread in German society, that it is best for a child's well being to be cared for in the home by the mother, until the age of 1 . Due to longstanding traditions dating back to the $19^{\text {th }}$ century French society suffers no such prejudices and it is socially acceptable for mothers of young children to enlist outside support in the upbringing of young children. The effects of these two approaches can clearly be seen when observing the sharply differing employment patterns for mothers in France and Germany. Irrespective of the number of children or the age of the youngest child, French mothers' employment rates remain higher than their German counterparts though the gap has been narrowing since the 1990s. German mothers also work part-time much more frequently than their French counterparts. It should come as no surprise that the gender gap in wages is more pronounced in Germany than in France: when taken as a whole the average annual earnings for females aged 30-44 
across all educational backgrounds in Germany were 57\% those of males compared to $74 \%$ in France in $2004 . .^{10}$ When the gender gap was measured in terms of median earnings for full-time employees, it was $23 \%$ in Germany compared to $12 \%$ in France (10). In addition, the proportion of women with managerial responsibilities in 2007 was only $27 \%$ in Germany as compared to $37 \%$ in France. ${ }^{11}$

Predicting future trends in German and French family polices is fraught with difficulties and by highlighting the challenges facing the two countries we can better appreciate the main obstacles that lie on the road ahead. In France, the challenge is two-fold and policymakers have found themselves in the uncomfortable position of trying to balance the needs of the family while at the same time responding to pressure from vested interests, e. g. labour unions or family associations. Changes in childcare policies are currently being driven more by the needs of the labour market than by the "best interests" of the child (Fagnani, 2009), a situation that serves to reinforce and strengthen the ambiguities and hybrid nature of French family policy. As for Germany, the view from France is that there is still a fundamental mismatch between the social norms governing childcare and the actual expectations and behaviour of young German women vis-à-vis paid employment.

Therefore, our comparative analysis suggests that a holistic approach to the interactions between reconciliation policies and patterns of paid and unpaid work is both necessary and appropriate.

\section{References}

Abrahamson, Peter (2007), "Reconciliation of work and family life in Europe: a case study of Denmark, France, Germany and the United Kingdom", Journal of Comparative Policy Analysis, 9 (2), pp. 193-209.

Ananian, Sévane, and Isabelle Robert-Bobée (2009), "Modes de garde et d'accueil des enfants de moins de 6 ans en France en 2007", Études et Résultats, 678.

Arts, Wil, and John Gelissen (2002), "Three worlds of welfare capitalism or more? A state-of-the-art report", Journal of European Social Policy, 12 (2), pp. 137-158.

Baclet, Alexandre, Fabien Dell, and Katharina Wrohlich (2007), “Composantes familiales des impôts sur le revenu en Allemagne et en France: les différences pertinentes", Economie et Statistique, 401, pp. 39-59.

Bailleau, Guillaume (2009), “L'offre d'accueil collectif des enfants de moins de 6 ans en 2007", Études et Résultats, 681.

Bertram, Hans, Hans Krüger, and Katharina Spiess (eds.) (2005), Wem Gehört die Familie der Zukunft. Expertisen zum 7. Familienbericht, Berlin, Ed. Barbara Budrich.

BmFSFJ (2009), Evaluationsbericht Bundeselterngeld, und Elternzeitgesetz 2009, Bundesministerium für Familie, Senioren, Frauen und Jugend, http://www.bmfsfj.de/bmfsfj/generator/BMFSFJ/Service/

10 Source: OECD (2009), Family Database, Gender Gap in Median Earnings of Full-Time Employees, 2006 or latest year available.

11 OECD (2009), Chart LMF6.5. 
Bode, Inge (2003), “The organisational evolution of the childcare regime in Germany: issues and dynamics of a public-private partnership", Annals of Public and Cooperative Economics, 74 (4), pp. 631-657.

Bothfeld, Silke (2005), Vom Erziehungsurlaub Zur Elternzeit, Politisches Lernen im Reformprozess, Frankfurt and New York, Campus Verlag.

CNAF (Caisse Nationale des Allocations Familiales) (2009), “L'activité des équipements d'accueil du jeune enfant en 2007", l'e-ssentiel, 91, pp. 1-4.

Destatis, Statistisches Bundesamt, 2009, https://www.ec.destatis.de/csp/shop/sfg/bpm.html

Dingeldey, Irene (2006), “Holistic Governance oder die Notwendigkeit reflexiver Gestaltung von Familien und Arbeitsmarktpolitik", in Hans Bertram (ed.), Wem Gehört die Familie der Zukunft. Expertisen zum 7, Familienbericht, Berlin, Ed. Barbara Budrich, pp. 359-382.

Dolowitz, David P., and David Marsch, (2000), “Learning from abroad: the role of policy transfer in contemporary policy making", Governance, 13 (1), pp. 5-24.

Erler, Daniel (2009), “Germany: taking a nordic turn?", in The Politics of Parental Leave Policies, London and New-York, Policy Press, pp. 119-134.

Eurobarometer (2006), Childbearing Preferences and Family Issues in Europe, Brussels, European Commission.

Eurostat (2008), La Vie des Femmes et des Hommes en Europe, European Commission.

Eurostat (2009), Demography Report, Brussels, European Commission.

Eurostat (2010), Statistics Database, Brussels, European Commission, http://epp.eurostat.ec.europa.eu (last consultation: 2010-01-31).

Evers, Adalber, Jane Lewis, and Birgit Riedel (2005), “Developing child-care provision in England and Germany: problems of governance", Journal of European Social Policy, 15 (3), pp. 195-209.

Fagnani, Jeanne (2006), "Family policy in France”, International Encyclopedia of Social Policy, vol. 3, Routledge, pp. 501-506.

Fagnani, Jeanne (2009), “Childcare policies in France: the influence of organizational changes in the workplace", in S. Kamerman, S. Phipps, and A. Ben-Arieh (eds.), From Child Welfare to Child Well-Being. An International Perspective on Knowledge in the Service of Making Policy, Child Indicators Research Book Series, 1, Springer, pp. 385-402.

Fagnani, Jeanne, and Antoine Math (2007), “Les récentes réformes de la politique familiale en Allemagne: de nouveaux horizons pour les femmes?", Droit Social, 5, pp. 630-636.

Fagnani, Jeanne, and Antoine Math (2008), “Family packages in 11 European countries: multiple approaches", in A. Leira, and C. Saraceno (eds.), Childhood. Changing Contexts, Comparative Social Research, 25, Bingley, Emerald, JAI, pp. 55-78.

Gornick, Janet, and Marcia Meyers (2003), Families that Work. Policies for Reconciling Parenthood and Employment, New York, Russell Sage Foundation.

Gornick, Janet, and Marcia Meyers (2006), “Welfare regimes in relation to paid work and care: a view from the United States on social protection in the European countries", Revue Française des Affaires Sociales, 1, pp. 167-188.

Grandke, Anita (2001), “Die Familienpolitik der DDR auf der Grundlage der Verfassung von 1949 und deren Umsetzung durch die Sozialpolitik", in G. Manz, E. Sachse, and G. Winkler (eds.), Sozialpolitik in der DDR. Ziele und Wirklichkeit, Berlin, Trafo-Verlag, pp. 317-336. 
Hall, Peter (1993), "Policy paradigms, social learning and the state: the case of economic policymaking in Britain", Comparative Politics, 25 (3), pp. 275-296.

Henninger, Annette, Christine Wimbauer, and Rosine Dombrowski (2008), “Geschlechterheit oder 'exclusive Emanzipation'? Ungleichheitssoziologische Implikationen der aktuellen familienpolitischen Reformen", Berliner Journal für Soziologie, 1, pp. 99-128.

Himmelweit, Susan (2007), “The prospects for caring: economic theory and policy analysis", Cambridge Journal of Economics, 31, pp. 581-599.

Holst, Elke (2005), “Women managers: enormous deficit in large companies and employer's associations", Wochenbericht, 4, https://www-ec.destatis.de

IMK (2008), Beschäftigung, Wirtschaftswachstum, Lohnentwicklung. Frankreich hat mehr erreicht als Deutschland, Berlin, Report 31, http://www.boeckler.de/37883_92391.html.

Institut für Demoskopie Allensbach (2007), Einflussfaktoren auf die Geburtenrate. Ergebnisse einer Repräsentativbefragung der 18 bis 44 jährigen Bevölkerung, IFD - Umfrage 5177.

Klammer, Ute, and Marie-Thérèse Letablier (2007), “Family policies in Germany and France: the role of enterprises and social partners", Social Policy and Administration, special issue, Reforming the Bismarckian Welfare Systems, 41 (6), pp. 672-692.

Lewis, Jane, Mary Campbell, and Huerta Carmen (2008a), "Patterns of paid and unpaid work in Western Europe: gender, commodification, preferences and the implications for policy", Journal of European Social Policy, 18 (1), pp. 21-37.

Lewis, Jane, Trudie Knijn, Claude Martin, and Iona Ostner (2008b), "Patterns of development in work/family reconciliation policies for parents in France, Germany, the Netherlands, and the UK in the 2000's", Social Politics, 15 (3), pp. 261-286.

Martin, Claude, and Bruno Palier (2007), “From 'a Frozen Landscape' to structural reforms: the sequential transformation of Bismarckian welfare systems?", Social Policy and Administration, 41 (6): 535-554.

Meyer, Traute (2005), "Political actors and the modernisation of care policies in Britain and Germany", in Birgit Pfau-Effinger, and Birgit Geissler (eds.), Care Arrangements and Social Integration in European Societies, Berlin, Policy Press, pp. 281-305.

Morel, Nathalie (2007), “From subsidiarity to 'free choice': child and elder care policy reforms in France, Belgium, Germany and the Netherlands", Social Policy and Administration, 41 (6), pp. 618-637.

Morel, Nathalie, Bruno Palier, and Joakim Palme (eds.) (2009), What Future for Social Investment?, Stockholm, Institute for Futures Studies.

Morgan, Kimberley J. (2002), "Forging the frontiers between state, church and family: religious cleavages and the origins of early childhood education and care policies in France, Sweden and Germany", Politics and Society, 30, pp. 113-148.

Morgan, Kimberley J. (2006), Working Mothers and the Welfare State, Stanford, Stanford University Press.

Muehler, Grit (2008), "Institutional childcare: an overview on the German market", Centre for European Economic Research (ZEW) Discussion Paper, 08-077.

OECD (2001), Lernen für das Leben. Erste Ergebnisse der internationalen Schulleistungsstudie PISA 2000, Paris.

OECD (2009), Family Database, www.oecd.org/els/social/family/database 
Ostner, Ilona (1993), "Slow motion: women, work and the family in Germany", in J. Lewis (ed.), Women and Social Policies in Europe, Aldershot, Edward Elgar, pp. 92-115.

Ostner, Ilona (2006), "Paradigmenwechsel in der (west)deutschen Familienpolitik", in P. A. Berger, and H. Kahlert (eds.), Der demographische Wandel. Chancen für die Neuordnung der Geschlechterverhältnisse, Frankfurt, Campus Verlag, pp. 165-202.

Palier, Bruno (2006), "The politics of reforms in Bismarckian welfare systems", Revue Française des Affaires Sociales, 1, pp. 47-72.

Pfau-Effinger, Birgit (2005), “Welfare state policies and the development of care arrangements", European Societies, 7 (2), pp. 321- 347.

Spiess, Katharina, and Katharina Wrohlich (2008), “Parental leave benefit reform in Germany: costs and labour market outcomes of moving towards the nordic model", Population Research and Policy Review, 27 (5), pp. 575-591.

Statistisches Bundesamt (2009), Öffentliche sozialleistungen Statistik zum Elterngeld. Anträge von Januar 2007 bis Juni 2008, Wiesbaden, https://www-ec.destatis.de/csp/shop/sfg/

Van Kersbergen, Kees, and Monique Kremer (2008), “Conservatism and the welfare state: intervening to preserve", in Wim van Oorschot, Michael Opielka, and Birgit Pfau-Effinger, Culture and Welfare State. Values and Social Policy in Comparative Perspective, Cheltenham, UK, and Northampton, MA, Edward Elgar, pp. 71-88.

Wrohlich, Katharina (2008), "The excess demand for subsidized child care in Germany", Applied Economics, 40, pp. 1217-1228.

Jeanne Fagnani. Senior research fellow at Centre National de la Recherche Scientifique (CNRS), Centre d'Économie de la Sorbonne, University of Paris 1. E-mail: fagnani@univ-paris1.fr

Antoine Math. Senior researcher, Institut de Recherches Economiques et Sociales (IRES), Paris. e-mail: antoine.math@ires-fr.org

\section{Resumo/ abstract/ résumé/ resumen}

Reformas recentes nas políticas da família em França e na Alemanha: desafios idênticos, respostas diferentes

Este artigo analisa se as reformas recentemente introduzidas nas políticas da família, tanto em França como na Alemanha, estão a direccionar os dois países para uma convergência. A Alemanha tem introduzido mudanças drásticas, especialmente um novo subsídio de licença parental, enquanto a França, por seu lado, optou por uma abordagem mais gradual que se tem traduzido por um reforço da promoção das suas políticas de conciliação trabalho-família juntamente com um aumento continuado da oferta de serviços de cuidados a crianças durante a última década. Apesar de um aumento na oferta global de equipamentos de cuidados a 
crianças, a Alemanha continua atrás da França neste domínio, fenómeno que pode ser parcialmente explicado por uma combinação de obstáculos institucionais, a persistência de normas sociais no que diz respeito aos cuidados a crianças com idades inferiores a três anos e uma procura excessiva. Defendemos que os principais motores para uma mudança paradigmática na Alemanha têm sido as preocupações com as consequências do declínio da fertilidade, da falta de trabalhadores qualificados e, segundo um estudo da OCDE, o desvanecimento de certezas sobre a educação infantil. Em França, as reformas nas políticas de licenças parentais têm apostado, por exemplo no maior encorajamento das mães a manter o vínculo laboral mesmo enquanto estão de licença. Mas, enquanto as reformas adoptadas por parte da Alemanha representam um corte radical com o antigo modelo masculino de provedor da família, as taxas de emprego das mães permanecem mais baixas do que em França e as mães alemãs trabalham com mais frequência a tempo parcial do que as suas homólogas francesas.

Palavras-chave políticas familiares, emprego, França, Alemanha, reformas.

Recent reforms in French and German family policies: similar challenges, different responses

This article investigates whether the recent reforms introduced in the family policies of both France and Germany are leading the two countries towards some measure of convergence. Germany has favoured dramatic changes, especially a new parental leave allowance, while France, for its part, has chosen a more gradual approach that has translated into an enhancement of its promotion of work-family reconciliation policies along with steady increases in spending related to childcare provision over the last decade. Despite a rise in its overall supply of childcare Germany still lags far behind France in this domain, a phenomenon that can be partially explained by a combination of institutional obstacles, the persistence of social norms governing childcare for under-3s, and excessive demand. We argue that the main drivers for paradigmatic change in Germany have been concerns over the consequences of declining fertility; a shortfall of qualified workers; and, the shattering of certitudes following an OECD study on childhood education. In France reforms in parental leave policies have been more incremental with, for example, mothers being encouraged to retain their links to the workforce even while on leave. But while the reforms adopted by Germany represent a radical departure from the former 'male-breadwinner model', mothers' employment rates remain lower than in France and German mothers work part-time with much greater frequency than their French counterparts.

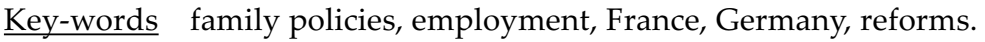


Les récentes réformes des politiques de la famille en France et en Allemagne: des défis similaires mais des réponses différentes

Nous analysons les réformes introduites depuis les années 1990 dans les politiques relatives aux aides à la conciliation travail/famille en France et en Allemagne et examinons si elles contribuent à une relative convergence dans ce domaine. L'Allemagne a réformé le congé parental (Elterngeld) en s'inspirant du modèle suédois, tandis que la France a poursuivi ses efforts en faveur des politiques d'accueil du jeune enfant sans pour autant modifier le dispositif du congé parental qui reste peu rémunéré. Outre-Rhin, tous les enfants âgés de trois à six ans bénéficient maintenant d'une place dans un jardin d'enfants, le plus souvent à temps partiel. L'accueil des enfants de moins de trois ans, en revanche, reste très limité. Des obstacles institutionnels, la persistance des normes éducatives et une forte demande expliquent ces différences entre les deux pays. Parmi les facteurs de changement, en Allemagne, figurent les préoccupations démographiques, la pénurie de travailleurs qualifiés et la volonté politique d'augmenter les taux d'emploi des mères, compte tenu de la diminution de la population active. La participation de celles-ci au marché du travail a beaucoup augmenté mais demeure moins élevée qu'en France et elles travaillent plus souvent à temps partiel que leurs homologues françaises. On peut conclure toutefois qu'on assiste à une relative convergence des politiques familiales des deux pays.

Mots-clés politique familiale, emploi, France, Allemagne, réformes.

Reformas recientes en las politicas de la familia en Francia y en Alemania: problemáticas semejantes, respuestas diferentes

Este artículo analiza si las reformas recientemente introducidas en las políticas de la familia, tanto en Francia como en Alemania, están direccionando a los dos países para una convergencia. Alemania ha introducido cambios drásticos, especialmente un nuevo subsidio de licencia parental. Francia, por su lado, optó por un abordaje más gradual que se ha traducido por un refuerzo de la promoción de sus políticas de conciliación trabajo-familia conjuntamente con un aumento continuado de la oferta de servicios de cuidado para niños durante la última década. A pesar de un aumento en la oferta global de equipamientos de cuidados para los niños, Alemania continua atrás de Francia en este dominio, fenómeno que puede ser parcialmente explicado por una combinación de obstáculos institucionales, la persistencia de normas sociales en lo que se refiere a los cuidados de niños con edades inferiores a tres años y una búsqueda excesiva. Nosotros defendemos que los principales motores para el cambio paradigmático en Alemania han sido las preocupaciones con las consecuencias del declive de la fertilidad, de la falta de trabajadores calificados y del desvanecimiento de certezas sobre educación infantil según un estudio de la OCDE. En Francia, las reformas en las políticas de licencias parentales han sido de mayor destaque, como, por ejemplo, la valentía de las madres por mantener 
el vínculo laboral aún estando de licencia. Sin embargo, las reformas adoptadas por parte de Alemania representan un corte radical con el antiguo modelo masculino de proveedor de familia, las tazas de empleo de las madres permanecen más bajas que en Francia y las madres alemanas trabajan con más frecuencia de tiempo parcial de que sus homólogas francesas.

Palabras-clave políticas de la familia, empleo, Francia, Alemania, reformas. 
